\title{
Articles
}

\section{EU Policy to Guarantee Procedural Rights in Criminal Proceedings: an Analysis of the First Steps and a Plea for a Holistic Approach}

\author{
Taru Spronken ${ }^{\star}$
}

\begin{abstract}
This article focuses on how procedural safeguards for suspects and defendants are protected by the European Convention on Human Rights and the increasing impact of the European Union in this area.

Criminal procedures vary enormously across European jurisdictions and so does the level of legal protection offered to suspects in criminal proceedings. Initial attempts by the European Union to establish minimum procedural rights for suspects and defendants throughout the EU failed in 2007, in the face of opposition by a number of Member States who argued that the European Convention on Human Rights (ECHR) and the enforcement mechanism of the European Court of Human Rights (ECtHR) rendered EU regulation unnecessary. However, with ratification of the Treaty, criminal defence rights appeared on the agenda again in order to increase mutual trust between Member States and thus improve the operation of mutual recognition. In November, 2009, the European Council adopted the Roadmap on Procedural Rights setting out a step-by-step approach to strengthen the rights of suspects and accused persons throughout the European Union. The first step has currently been taken through the adoption of the Directive on the right to interpretation and translation in criminal proceedings of 26 October, 2010, with two EU legislative proposals on the table: one on the right to information and one on the right to legal assistance in criminal proceedings. In parallel with these developments, two research projects have been conducted. One into the way suspects and defendants are informed of their rights throughout the EU and another one on access to effective defence in criminal proceedings across nine European jurisdictions that constitute examples of the three major legal traditions in Europe: inquisitorial, adversarial and post-state socialist. The outcomes of this research are the basis for critical analysis of the way EU policy aims to fill the gaps in human rights protection in the area of criminal procedural law.
\end{abstract}

\footnotetext{
* Prof. Dr. Taru Spronken, Department of Criminal Law and Criminology, Faculty of Law, Maastrich University. This article is a revised and actualised version of a paper presented by the author and Dr. Dorris de Vocht (Maastricht University) at the conference The Future of the Adversarial System on 1 April, 2011, at the University of North Carolina School of Law at Chapel Hill, North Carolina,, USA.
} 